\title{
일본의 개발협력인재 육성사업 현황과 시사점
}

- 국제개발협력 분야에서도 사람이 답이다 -

목 차

\section{I. 서론}

II. 일본의 개발협력인재 육성 전략

1. 주요 정책 및 전략 문서

2. 개발협력인재 육성 계획 수립 절차

III. 개발협력인재의 핵심 역량 이해

1. 글로벌 역량과 개발협력

2. JICA의 개발협력인재의 역량 요소

3. 개발협력인재의 역량 요소 변화

IV. 일본의 개발협력인재 육성사업 추진 현황

1. 개발협력인재 육성사업 개관

2. JICA의 개발협력인재 육성 추진 체계 및 PARTNER

3. JICA의 국제협력 전문 인력 활용 현황

V. 결론 및 정책적 시사점

참고 문헌 


\section{요 약}

일본에서는 효과적인 개발협력을 수행하는 데 우수한 개발인재가 필수적이라는 신념 에 기초해 1980년대 후반부터 우수 인재의 육성 및 확보에 적극 대처해 왔다. 이에 일본 정부는 2003 년 $\mathrm{ODA}$ 헌장 개정 시에도 국민 참여를 확대하기 위한 주요 전략으로 개발인재 육성, 개발연구 및 개발교육을 강조한 바 있다. 또한 2010년 6월에는 "ODA 검토 최종보고서”에서 개발인재 육성을 중점 방침으로 제시하는 등 개발인재 육성을 위한 다양한 사업을 추진해 왔다.

최근 한국 정부는 한국국제협력단(Korea International Cooperation Agency, $\mathrm{KOICA}$ )을 중심으로 '글로벌인재양성1)사업'을 통해 배출되는 인력 중 국제개발협력 분야로 진출을 희망하는 인재들이 경력사다리를 통해 올라갈 수 있도록 귀국 후 보수교 육, 취·창업 컨설팅 등을 지원하기로 방침을 정한 바 있다. $\mathrm{KOICA}$ 의 개발협력인재 양성 지원 사업은 한국의 개발원조 효과성을 제고하는 데도 필수적인 요소일 뿐만 아니 라 공공기관으로서 글로벌인재 양성 지원과 좋은 일자리 창출 등 사회적 가치 실현 측면에서도 중요하다.

따라서 본 원고에서는 일본 국제협력기구(Japan International Cooperation Agency, $\mathrm{JICA}$ )의 관련 사업을 중심으로 일본의 개발협력인재 육성 전략과 주요 지원 사업 현황을 살펴봄으로써 한국 정부 및 $\mathrm{KOICA}$ 에 주는 시사점과 교훈을 도출하고자 한다.

1) 한국은 인재 양성이라는 용어를 사용 중인데, '양성'은 '가르쳐서 유능한 사람을 길러 낸다', 혹은 '실력이나 역량 등을 키워서 발전시킨다'는 뜻이다(http://krdic.naver.com/detail.nhn?docid=25857600, 2017.11.27.). 이는 특정 역량을 겸비한 인재 양성이 목적이므로 '양성'이라는 용어가 타당한 것으로 사료된다. 반면, 일본은 인재 육성이라는 용어를 사용 중인데, '육성'은 사전적 개념으로 '길러 자라게 한다'는 뜻이다.

(http://krdic.naver.com/search.nhn?dic_where=krdic\&query=\%EC\%9C\%A1\%EC\%84\%B1, (접속일: 2017. 11.27.) 일본의 경우에는 개발인재 육성 시 불특정 다수를 대상으로 저변 인재부터 특정 역량을 겸비한 개발협력인재에 이르기까지 포괄적인 전략에 따른 개발인재 육성 체계가 구축되어 있다. 


\section{I. 서론}

두 번의 세계대전으로 전쟁의 참상을 겪은 국제사회는 제 2 차 세계대전 이후 국제 연대를 통해 빈곤을 퇴치하고 평화를 정착시키며, 모든 인류가 평등하고 자유로운 여건에서 보다 나은 삶을 영위하기 위한 국제 레짐(international regime)으로서 '공적개발원조(Official Development Assistance, 이하 ODA)'를 탄생시켰다. 그러나 지난 70여 년의 역사 속에서 ODA는 '미완의 과제(unfinished business)'로 남아 있다. 즉, 그동안 인구의 수명 증대, 안전한 물 이용 인구 증대, 절대빈곤 인구 감소 등 괄목할 만한 개발원조 성과에도 불구하고 여전히 빈곤, 인구, 질병, 테러, 인권, 환경 등 더욱 복합적이고 다면적인 개발 이슈에 직면해 있다. 이에 국제사회는 측정 가능한 목표를 수립하여 성과 중심의 원조 관리를 강화하고, 원조 효과성(aid effectiveness)을 넘어 개발 효과성(development effectiveness)을 제고하기 위한 다양한 논의와 조치를 강구하고 있다.

한정된 재원으로 실질적인 개발 성과를 어떻게 제고해야 하는가는 개발 전략가 혹은 개발 실천가들의 가장 큰 고민 중 하나다. 국제사회의 변화나 흐름에 맞는 사업 전략과 목표 수립, 새로운 사업 유형과 방법론 개발, 관련 제도 및 시스템 구축, 모니터링·평가 및 평가 교훈의 피드백 강화 등 다양한 노력에도 불구하고 개발 현장에는 늘 예측하기 어려운 여러 위험이 도사리고 있기 때문이다. 자본과 기술, 행정 역량 등이 전반적으로 취약한 개발 현장에서 많은 자원과 역량이 위험 관리나 문제 해결에 투입된다. 이때 어떤 문제가 심각하게 발생하거나 혹은 다른 사례보다 성과가 높은 경우에 그 요인들을 들여다보면, 결국 '사람'의 문제로 귀결된 다는 것을 경험하게 된다. 따라서 개발협력 분야에서도 사업에 개입하는 많은 이해관계자의 지식, 경험, 리더십, 열정 등이 사업 성과에 많은 영향을 미친다.

경제협력개발기구(Organization for Economic Cooperation and Development, 이하 $\mathrm{OECD}$ ) 개발원조위원회(Development Assistance Committee, 이하 DAC)는 "더 나은 원 조(Better Aid)보고서”에서 ‘효과적인 개발협력은 숙련되고 경험 있는 인력에 달려 있다’고 분석하며, 개발에 대한 심층적인 이해, 현장에 대한 이해, 높은 동기부여 등 인적자원 관리의 중요성을 강조한 바 있다 $(\mathrm{OECD}, 2005: 39)$. 따라서 경제·사회·환경을 포괄하는 변혁적 (transformative)이고, '누구도 소외되지 않도록(leaving no one behind)' 포용적(inclusive) 인 지속가능개발목표(Sustainable Development Goals, 이하 SDGs)를 효과적으로 달성하 기 위해서는 더욱 다양한 개발 분야의 전문성과 지역 및 협력 대상국에 대한 심층적인 이해와 함께 실행 역량을 갖춘 전문 인력이 필요하다. 
현재 한국은 경제력에 상응한 수준으로 ODA를 실시하고 있지는 못하지만, 지속적으로 $\mathrm{ODA}$ 규모를 확대해 선진국과 개발도상국 간 교량 역할을 수행하는 데 많은 노력을 기울여 왔다. $\mathrm{ODA}$ 규모가 확대되면서 다양한 분야의 전문가 및 실무 인력의 수요가 늘어나고 있는 바, 한국도 효과적인 개발협력을 추진하기 위해서는 개발협력인재 육성에 대한 정부 차원의 체계적인 대응 전략 수립과 구체적인 프로그램 시행이 어느 때보다도 필요하다.

요즘 한국에서는 국제개발협력 관련 대학 및 대학원에서 매년 배출되고 있는 인재2)들과 개발도상국에서 다양한 경험과 지식을 쌓은 해외봉사단 및 영프로페셔널3) 등 귀국 인재들의 경험이 국가 자산으로 잘 활용되고 있지 못하다는 지적이 많다. 또한 개발도상국에 대한 심층적인 이해와 경험을 갖춘 전문 인력이 부족하고, 개발협력 분야의 전문 인력 수요와 공급 간 수적인 불균형뿐만 아니라 개발협력 업무 수행에 필요한 실질적인 역량을 갖춘 인재가 부족하다는 지적도 동시에 제기되고 있다. 일부 국제 비정부기구(International Non-Governmetal Orgnizations, 이하 INGOs)나 일정 규모를 갖춘 시민사회단체(Civil Society Organizations, CSOs)를 제외한 영세 NGOs의 경우에는 처우가 열악하거나 무보수 인턴 등을 많이 활용하고 있다는 문제도 거론되고 있다.

한국국제협력단(Korea International Cooperation Agency, 이하 KOICA)이 국정자문기 획위원회에 보고한 '글로벌인재양성 및 양질의 일자리창출기본계획(안)'에 따르면, 향후 봉사단 이나 영프로페셔널(청년 인턴) 등 우수 인재 유입을 위한 인센티브 확대, 귀국 후 보수교육 및 취·창업 컨설팅 등 경력개발 기회 제공, 귀국 인재의 $\mathrm{KOICA}$ 정규직 채용 확대, 국제기구 사업에 한국의 인력 투입 제도화 등을 통해 향후 5 년간 3,000 명(직·간접)을 고용할 계획이다.4) 이에 KOICA ODA교육원은 동 계획의 일환으로 2018년부터 '귀국 인재 대상 보수교육'을 실시할 계획이다. 이처럼 $\mathrm{KOICA}$ 의 개발협력인재 양성 지원 사업은 한국의 개발원조 효과성을 제고하는 데도 필수적인 요소일 뿐만 아니라 공공기관으로서 글로벌 인재 양성 지원과 좋은 일자리 창출 등 사회적 가치 실현 측면에서도 중요한 정책 과제 중 하나다.

한편, 일본 정부는 효과적인 개발협력을 수행하는 데 우수한 개발인재가 필수적이라는 신념 에 기초해 1980년대 후반부터 우수 인재 육성 및 확보에 적극 대처하고 있다. 일본 정부는

2) 한국교육개발원 교육통계(2017)에 따르면, 한국의 국제학 관련 학과(국제개발협력학 등)에는 74 개 학과가 설치되어 있으며, 매년 1,600 여 명의 졸업생이 배출되고 있다. 아울러 국제개발, 국제학, 국제개발협력, NGO 등 개발협력 관련 대학원 석사과정에 1,000여 명의 대학원생들이 재학 중인 것으로 파악된다(출처: https://kess.kedi.re.kr/index). (접속일: 2017.12.21.) 일본 관련 통계는 피장 1절 각주 5 참조.

3) '영프로페셔널(Young Professional)'은 2010년에 도입된 ODA 청년인턴의 새로운 명칭이다.

4) KOICA 내부 자료(2017.6.) 
2003년 ODA 헌장 개정 시에도 국민 참여 확대를 위한 주요 전략으로 개발인재 육성과 개발연 구, 개발교육을 강조하고 이를 위한 다양한 사업을 추진 중이다. 따라서 본 원고에서는 일본 국제협력기구(Japan International Cooperation Agency, 이하 JICA)의 관련 사업을 중심으로 일본의 개발협력인재 육성 전략과 주요 지원 사업 현황을 살펴봄으로써 한국 정부 및 $\mathrm{KOICA}$ 에 주는 시사점과 교훈을 도출하고자 한다.

제I 장

제II장

포

커

스

제피장 


\section{II. 일본의 개발협력인재 육성 전략}

\section{1. 주요 정책 및 전략 문서}

앞서 밝혔듯이, 일본 정부는 효과적인 개발협력을 위해서는 우수한 개발인재가 반드시 필요 하다고 인식해 1980년대부터 우수 인재 육성 및 확보에 적극 대처하고 있다. 특히 2003년 'ODA 헌장' 개정 시에는 국민 참여 확대를 주요 전략으로 수립하고 인재육성, 개발연구 및 개발교육을 적극 추진 중이다. 이밖에도 개발인재육성의 상위 정책으로 'ODA 중기정책'(2005 년 2월 시행), ${ }^{\circledR} \mathrm{ODA}$ 검토(ODA Review) 최종 보고서』5)(2010년 6월)를 들 수 있으며, 주요 내용을 정리하면 아래와 같다.

〈표 1〉 개발인재 육성의 주요 정책 및 전략문서 관련 내용

\begin{tabular}{|c|c|c|}
\hline $\mathrm{ODA}$ 헌장 & $\mathrm{ODA}$ 중기정책 & $\mathrm{ODA}$ 검토 최종 보고서 \\
\hline $\begin{array}{l}\text { 으개발인재 육성과 개발연구 } \\
\text { 전문성이 있는 인재를 육성 } \\
\text { 하고, 이러한 인재가 국내 } \\
\text { 외에서 활용할 수 있는 기 } \\
\text { 회를 확대하는 데 노력한 } \\
\text { 다. }\end{array}$ & $\begin{array}{l}\text { 억절한 인원 배치와 인재육성 } \\
\text { 현지 기능을 강화하고 원조 협조 등 국 } \\
\text { 제 동향이나 일본의 원조 정책 실시 전 } \\
\text { 반에 관해 폭넓은 경험과 식견이 있는 } \\
\text { 인력 확보가 필수적이다. 따라서 현지 } \\
\text { 및 동경 양측에서 IT 등을 활용해 연수 } \\
\text { 를 내실화하고, 원조에 종사하는 인재 } \\
\text { 육성을 통해 일본 원조의 저변을 확대하 } \\
\text { 도록 한다. }\end{array}$ & $\begin{array}{l}\text { 8-1 육성 프로그램 내실화로 개발인재의 } \\
\text { 시야 확대(연수 프로그램 확충, 개발 } \\
\text { 현장에서 지도적 역할 수행 인재육 } \\
\text { 성) 지금까지 실시해 온 국제개발 } \\
\text { (IDS) 석사과정 프로그램 실시 기관, } \\
\text { 프로그램, 대상자 등을 재검토해 국 } \\
\text { 제기구, NGO, 전문가 등 개발협력 } \\
\text { 현장에서 활약하는 인재에 대해 고도 } \\
\text { 의 실무교육을 실시하고 또 중재 역 } \\
\text { 할 등 현장에서 지도적 역할을 수행 } \\
\text { 하는 인재를 육성한다. }\end{array}$ \\
\hline
\end{tabular}

출처: IDCJ (2014) p.51 내용을 저자가 재구성

개발협력 역사가 오래된 서구의 경우, 개발협력 인재를 양성하는 중심축은 국제개발 혹은 국제협력 관련 전공을 개설하고 있는 대학교라고 할 수 있다.6) 이밖에도 다양한 컨설팅

5)『일본 ODA검토 최종보고서』에 대한 자세한 사항은 다음에서 확인 가능하다. http://www.mofa.go.jp/mofaj/gaiko/ oda/kaikaku/arikata/pdfs/saisyu_honbun.pdf (접속일: 2017.11.29.)

6) IDCJ. 2014. 『개발인재 육성 및 개발교육 지원 평가 보고서』에 따르면, 대학원 등 국제협력이나 국제개발학 석 - 박사 학생 수는 2005년을 기점으로 연간 1,000여 명을 상회하는 것으로 나타나고 있다. 2011년 통계로 보면 석사 729명, 박사 384 명이 관련 석 · 박사과정에 재학 중이다(p.14). 국제관계학과 대학생도 연간 3,000명 이상 배출되고 있으며, 2012년 재학생 수는 12,976명에 달한 것으로 조사되었다(p.32). https://kess.kedi.re.kr/frontPop/publView?publitemId= 70378\&survSeq=2017\&publSeq=2(접속일: 2017.11.24.) 
회사, 개발협력 참여 기업, 개발 NGO, 원조 기관 등을 통해서도 업무를 통한 개발협력 전문 인력 양성이 이루어진다고 볼 수 있다. 일본의 경우에도 개발협력 인재를 양성하는 중심축은 국제개발 전공 등 대학 및 대학원인데, 일본의 개발인재 육성의 전체상을 보면 아래 <그림 $1>$ 과 같다. 일본의 경우 $\mathrm{NGO}$ 인재는 개발협력 인재와 차별화해 사업 실시 능력이나 조직력 강화 등에 초점을 맞추어 인재 육성을 지원하고 있는데, 관련 내용은 <그림 $2>$ 를 참조하기 바란다.

\section{〈그림 1〉 일본의 개발협력인재 육성 전체상}

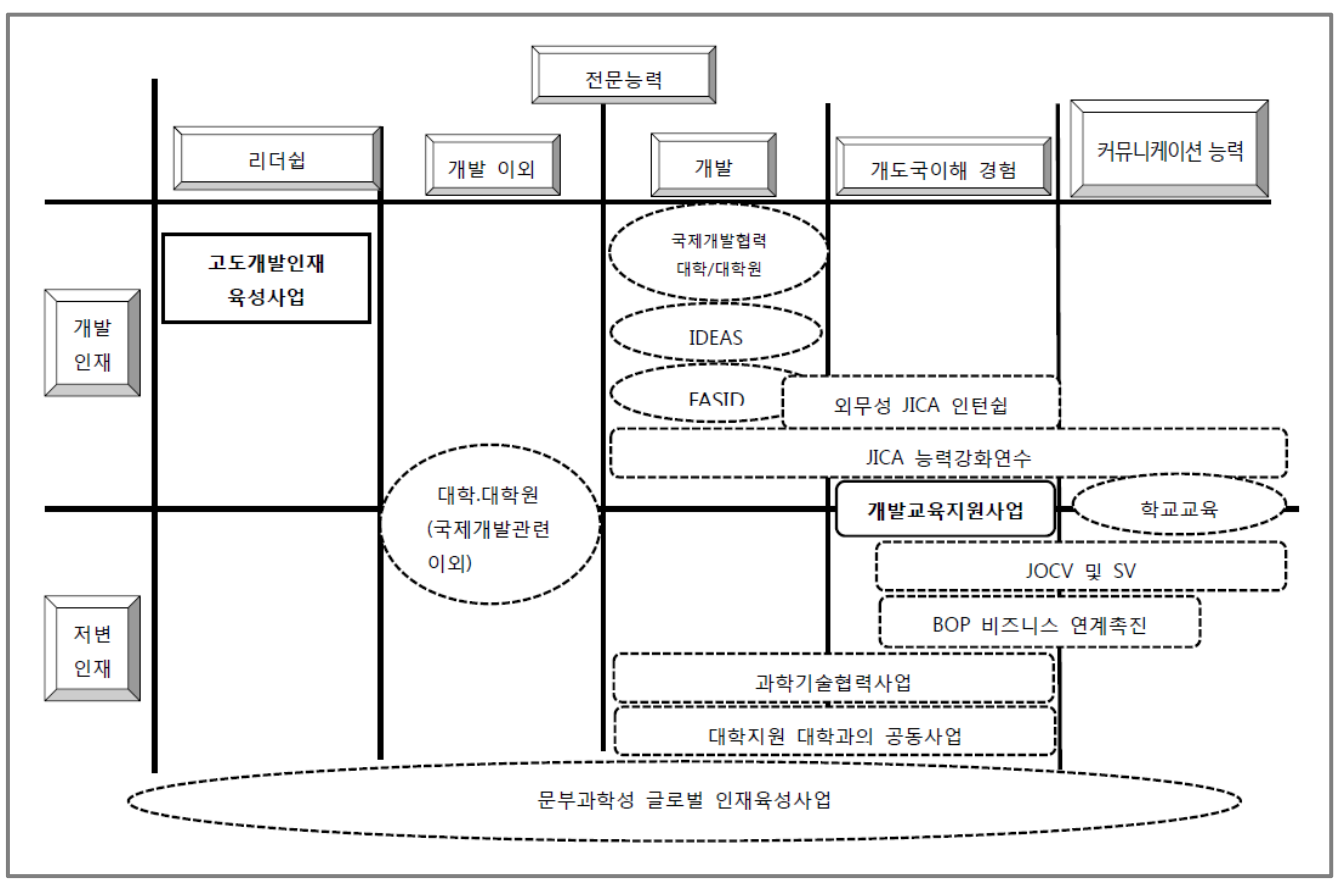

출처 : IDCJ (2014) p.107)

7) <그림 $1>$ 의 약칭을 설명하면 다음과 같다. IDEAS는 아시아경제연구소(IDE-JETRO)가 운영하는 개발 스쿨로, 일본인과 외국인을 대상으로 한 프로그램을 운영 중이다. 일본인을 대상으로 한 연수 과정은 경제협력, 개발원조 분야 경력 개발을 희망하는 전문 인력을 양성하는 1 년 과정(비학위 과정)이다. $\mathrm{FASID}$ (일반 재단법인 국제개발기구) 는 국제개발 분야 전문 인력을 양성하기 위해 1990년에 설립되었다. 인재양성 외에도 조사·연구, 컨설팅 사업을 추진 중이다. JOCV는 JICA가 파견하는 일본해외협력대를 의미하며, SV는 시니어봉사단을 의미한다. $\mathrm{BOP}(\mathrm{Base}$ of the Pyramid)는 빈곤층을 의미한다. 
〈그림 2〉 일본의 개발협력인재 육성 정책 체계도

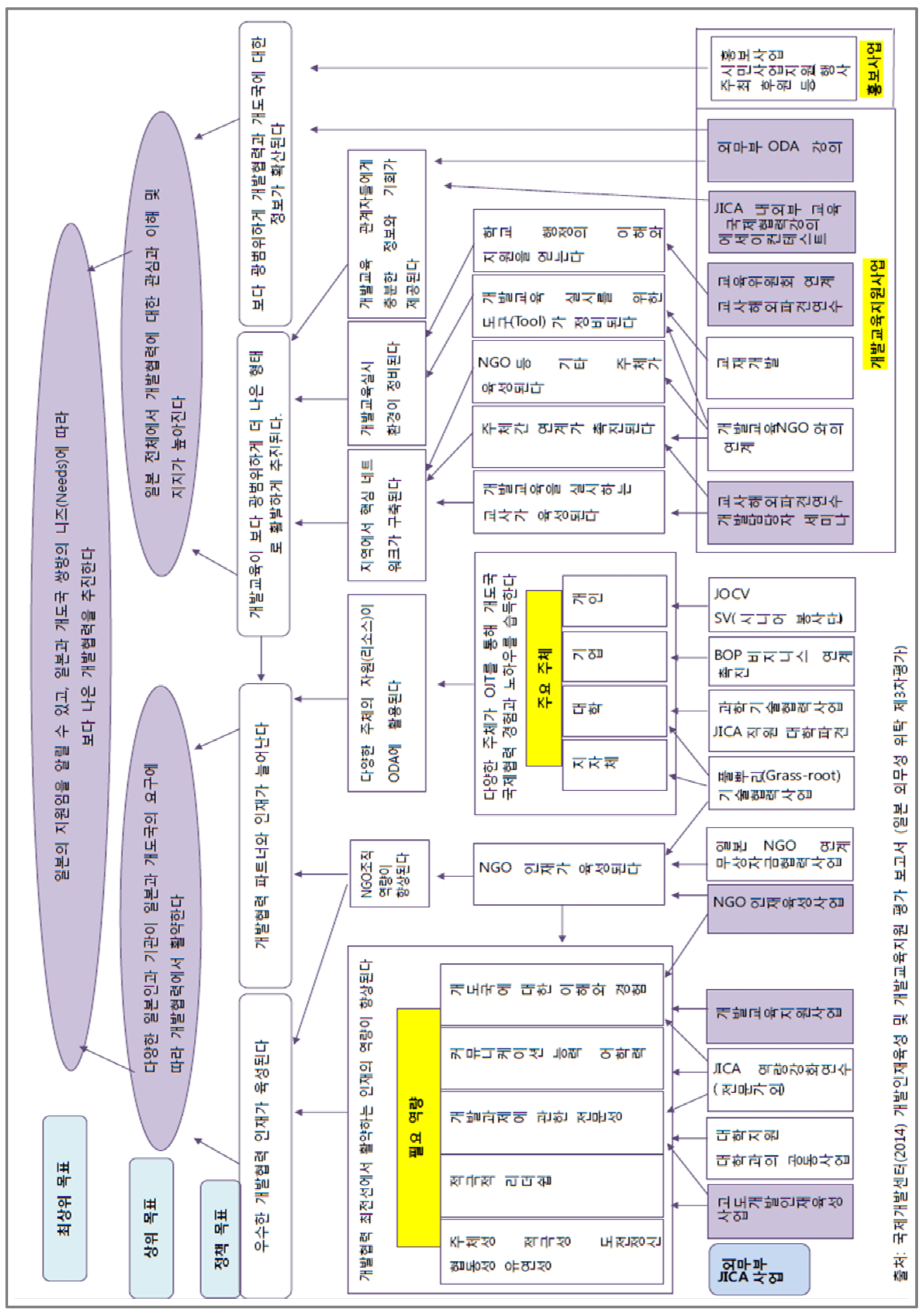




\section{2. 개발협력인재 육성 계획 수립 절차}

개발협력인재 육성 계획을 수립할 때 우선, 인재의 정의와 핵심 역량을 도출하는 것이 필요할 것이다. IDCJ(2014)는 『개발인재 육성 및 개발교육지원 평가 보고서』에서 개발협력인재 수요에 부합된 인재 육성을 위해서 일반적으로 개발인재 수요의 명확화, 개발인재 육성 전략과 계획 수립, 전략 및 계획에 기초한 실행 등 3 단계로 추진되어야 한다고 제시했다. (<표 $2>$ 참조)

〈표 2〉 수요에 부합된 개발협력인재 육성 절차(안)

\begin{tabular}{|c|c|c|}
\hline 구분 & 내용 & 명확히 해야 할 사항 \\
\hline 1단계 & 요구의 명확화 & $\begin{array}{l}\circ \text { 개발인재의 정의 } \\
\circ \text { 개발인재에 필요한 역량 }\end{array}$ \\
\hline 2단계 & $\begin{array}{l}\text { 개발인재 육성을 위한 계획 및 } \\
\text { 전략 수립 }\end{array}$ & $\begin{array}{l}\circ \text { 달성해야 할 수준 } \\
\circ \text { 개발인재 육성 방법의 방향성(외무성 JICA가 담당할 역할과 } \\
\text { 업무 분장) } \\
\text { 개발인재 육성, NGO인재 육성 및 개발교육지원 등 관계 정립 }\end{array}$ \\
\hline 3단계 & 계획 및 전략에 기초한 실시 & \\
\hline
\end{tabular}

출처 : IDCJ (2014) p.53 내용을 저자가 재구성

이때 각 단계별로 인재의 정의, 역량, 달성 수준, 인재 육성 방법의 방향성 등이 명확히 수립되어 있어야 한다. 일본의 경우에도 이러한 요소들이 미흡하게 운영되고 있는 것으로 평가되었다(IDCJ, 2014: 53). 개발협력인재가 활동하는 영역은 <그림 3>과 같이 다양한데, 각 기관들이 요구하는 자격이나 역량, 경험 수준에는 공통점도 있겠으나 차이점도 존재한다. 따라서 각 기관의 인재 수요를 분석하고, 경력개발 계획에 따라 맞춤형 교육과정들이 단계별로 지속 제공될 필요가 있다.

\section{〈그림 3〉 개발협력 활동주체(actor)}

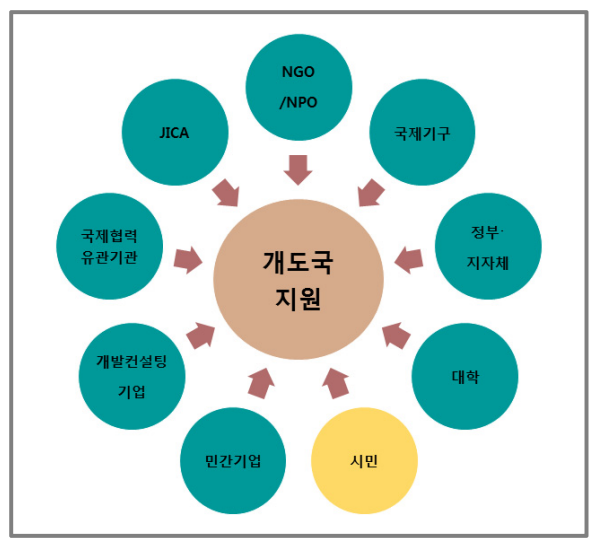

출처: JICA 'PARTNER' 홈페이지(http://partner.jica.go.jp/ContentViewer?prm=AboutField 1\#2) (접속일: 2017.11.28.) 


\section{III. 개발협력인재의 핵심 역량 이해}

\section{1. 글로벌 역량과 개발협력}

다음으로는 개발협력인재에 필요한 역량에 관해 살펴보기로 하겠다. 우선 개발협력인재가 글로벌한 여러 이슈를 다루고 또 국제 무대에서 활동하는 만큼 글로벌 인재와 역량 요소에서 공통점이 있다고 할 수 있다.

$\mathrm{OECD}(2016)$ 는 “포용적인 세계를 위한 글로벌 역량(Global competency for an inclusive world)” 보고서에서 글로벌 역량을 지식, 기술, 태도 세 가지 차원에서 분석하고 있다. 그러면서 '글로벌 역량이란 글로벌하고 이문화적인 이슈들을 다각적인 관점에서 비판적으로 분석할 수 있는 능력과 차이(differences)가 자신과 타인의 지각 - 판단·아이디어에 어떻게 영향을 미치 는지 이해하는 능력, 인간의 존엄성에 관한 공유 가치를 기반으로 다른 배경의 사람들과 개방적 이고 적절하며 또 효과적으로 상호작용을 할 수 있는 능력'이라고 정의하고 있다(김복희, 2017).

이러한 글로벌 역량 요소는 개발협력인재의 핵심 역량 요소라기보다는 공통 역량 요소라고 할 수 있는데, 이는 개발도상국의 개발 현장에서 사업을 수행하는 개발 실천가들에게는 매우 중요한 역량 요소 중 하나다. 여기서 주목할 점은 $\mathrm{OECD}(2016)$ 가 정의한 ‘글로벌 역량은 단순 히 '글로벌' 혹은 '세계화’ 관점에서 뿐만 아니라 '현지화' 관점에서 현지 여건이나 사회문화적 차이와 영향에 대한 이해를 강조하고 있다는 점이다. 따라서 개발협력인재에게 요구되는 공통 역량 요소이자 덕목은 다양한 글로벌 개발 의제에 대한 이해뿐만 아니라 현지에 대한 철저한 분석과 이해 그리고 존중이라고 할 수 있다.

〈그림 4〉 글로벌 역량 요소와 핵심 가치

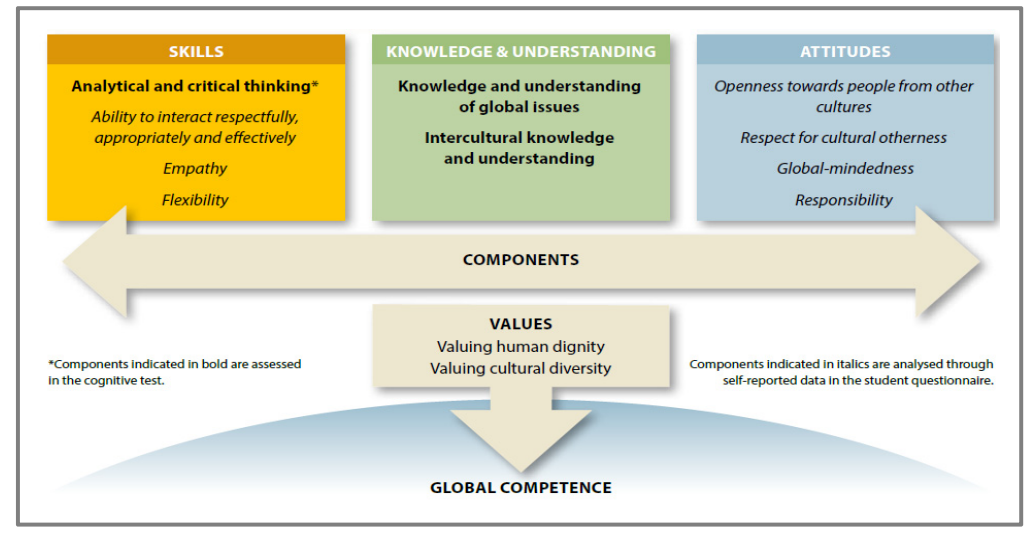

출처: OECD (2016) p.10 내용을 저자가 재구성 


\section{JICA 개발협력인재의 역량 요소}

앞서 밝혔듯이, 오늘날 개발 과제는 더욱 복합적이고 다면적인 양상을 보이고 있다. 또 민간 재원 등 다양한 혁신적 개발 재원의 등장과 함께 사업 방식도 다각적으로 진화되고 있어 개발협 력인재에게 요구되는 전문성 역시 더욱 포괄적이고 심화되고 있는 추세다. 따라서 다양한 지식 과 경험을 지닌 인재를 확보하는 것은 개발협력 사업의 성과 관리 측면에서도 중요한 과제다.

$\mathrm{JICA}$ 는 국제협력인재 요소를 아래 <그림 $5>$ 와 같이 6 개 차원에서 분석해 제시하고 있는데, $\mathrm{KOICA}$ 의 핵심 역량 요소와 유사한 점을 볼 수 있다.8) 이번에는 여러 제약으로 인해 다른 공여국의 사례는 조사하지 못했는데, 유사성이 많을 것으로 판단된다. 향후 구체적인 교육 프로 그램 설계 과정에서는 국제기구 진출 등 다양한 경력개발 설계 및 교육을 위해 다른 공여국 및 국제기구에 대해서도 비교조사가 필요할 것이다.

〈그림 5〉 JICA의 국제협력인재 역량 요소

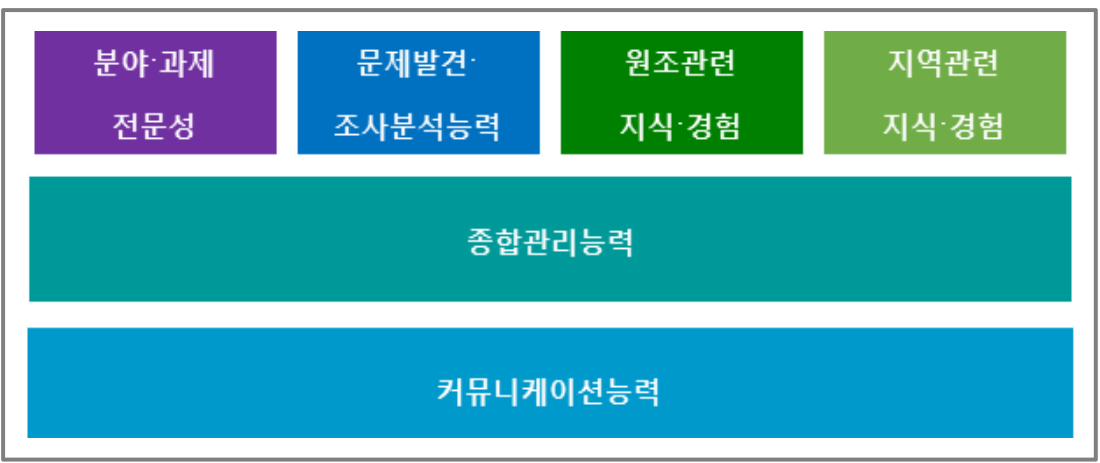

출처: JICA 'PARTNER' 홈페이지 (http://partner.jica.go.jp/resource/1491681488000/shigoto/ 6abi.html) (접속일: 2017.11.08.)

위 <그림 $5>$ 에서 분야 과제 전문성이란 특정 분야나 과제의 전문 지식과 경험을 토대로 그 지식을 수원국의 자연 - 사회•경제 등 각 환경이나 제도 그리고 능력 등에 맞게 적용할 수 있는, 이른바 적정기술과 지식을 선택할 수 있는 두 가지 능력을 포함한다. 여기서 특정 분야 및 과제의 전문 지식이나 경험이란 대학이나 대학원 전공을 기반으로, 이후 실무 경험을

8) $\mathrm{KOICA}$ 의 역량 모델은 공통 역량(전문성, 개방성, 창의, 파트너십, 도덕성), 리더십 역량(비전 제시, 조직 관리, 성과 관리, 실행력 등), 직무 공통 역량(국제개발협력, 커뮤니케이션, 정보 수집 및 분석, 기획력, 문제 해결, 프로젝트 관리)으 로 구분되어 있으며, 경력개발 계획에 기반을 두고 교육훈련 계획을 수립해 운영 중이다. (출처: 한국국제협력단 (2016) 내부 자료) 
통해 학교에서 배운 지식이 능력으로 향상되는 것을 의미한다. 또한 적정기술이나 지식의 선택 (개발) 기량은 개발도상국에서의 실무 경험이나 과거 사례의 학습을 통해 몸에 익히는 것이다. 이때 문제 발견이나 정보수집 분석 능력은 조사 업무에서 필수적인 능력(평가 업무 포함)인데, 기술이전 업무에서도 문제의 소지를 발견해 해결책을 검토하는 데 필요한 정보를 수집 및 분석 하고 가설을 세우는 능력이 필요하다. 여기에는 인터뷰 기술이나 인맥 형성의 노하우, 조직 내 정보 유통에 관한 지식, 각종 조사기법 활용 능력, 수집된 정보에서 결론을 얻기까지 프로세 스에서 요구되는 데이터 이해와 해석 등 통계학을 구사한 데이터 해석 능력을 포함한다. 또한 원조 관련 지식이나 경험이란 각 원조 기관의 특성이나 상호 관계, 주요 사업 체계의 내용 등 원조 관련 기초 지식부터 최신 원조 동향에 이르기까지 다양한 원조 관련 지식과 더불어 개발 원조 현장이나 원조 기관에서 축적한 실무 지식 및 경험을 의미한다. 또 지역 관련 지식과 경험이란 특정 국가나 지역의 정치, 경제, 사회, 문화, 역사, 자연 등에 관한 지식이나 특정 국가 및 지역에서 쌓은 경험을 의미한다.

그리고 종합관리 능력이란 특정 문제를 해결하기 위해 문제 해결의 방향성을 제시하고 필요 한 자원을 동원해 문제를 해결하는 능력(문제해결능력), 다양한 관계자와 협의 및 조정하고 시시각각 변화하는 환경에 대처하면서 사업이나 업무 목표를 일정 기간 내에 달성하는 능력 (사업 업무관리 능력)을 의미한다. 종합관리 능력에는 카운터파트에게 기술을 전수하고, 그들 스스로 실시할 수 있도록 가르치는 코칭 능력 혹은 카운터파트를 둘러싼 제도 및 조직 개선을 촉구·실현하는 능력(인재 육성, 조직 강화 능력) 등을 포함한다.

마지막으로, 커뮤니케이션 능력에는 영어나 현지어 등 업무상 필요한 의사소통 능력 외에도 자신이 말하고자 하는 것을 상대방에게 전달하는 능력(프레젠테이션)이나 전달 방법(교섭)의 노하우를 포함한다. 따라서 이문화 환경에서 상대방과의 원활한 커뮤니케이션의 기초가 되는 사회성이나 협조성, 상대가 처해 있는 상황에 공감하는 능력 등 커뮤니케이션 능력을 뒷받침하 는 자질이 필요하다.

\section{3. 개발협력인재의 역량 요소 변화}

글로벌 역량과는 차별화되는 개발협력인재의 핵심 요소에는 어떤 것들이 있을까? IDCJ (2014)에 따르면, 과거에는 개발협력에 특화된 형태의 개발협력인재가 요구되었다. 그러나 최 근에는 전문성의 한 부분으로써 개발협력에 대한 니즈(needs)가 변화하고 있으며, 개발 전문 분야도 더욱 다양화되고 있는 것으로 분석되고 있다. 아울러 세계화로 인한 환경 변화에 따라 개발에 관한 인식, 개발도상국을 포함한 국제이해와 경험에 관한 인식도 ODA 영역만이 아니라 
비즈니스, 지역 등 폭넓은 분야에서 개발에 관한 인식의 중요성이 증대되고 있다.

또한 아래 <상자 1 >과 같이 일본에서는 국제협력 실시 기관이나 컨설팅 회사, NGO 등 국제협력 및 $\mathrm{ODA}$ 전문 기관만이 아니라 민간 기업을 포함해 조직 간 인재 유동화 사례가 폭넓게 증가하고 있는 것으로 분석되었다. 아울러 경력개발 경로를 보면, 국제개발 관련 전공자 들이 JICA나 국제개발컨설팅 기업에 반드시 채용되지 않는 것으로 분석되었다. ODA 관련 취업률을 볼 때 아시아경제연구소개발스쿨(Institute of Developing Economies Advanced School, IDEAS)은 절반 정도, 국제개발 관련 대학원의 경우에는 비율이 낮은 편인 것으로 분석되었다. JICA의 경우에도 국제개발 관련 대학원 졸업생 채용을 특별히 확대하고 있지는 않다고 한다. 한편, 공학계 전문 지식과 국제 경험을 갖춘 대학 및 대학원 졸업자에 대한 수요도 높아지고 있는 추세로, ODA 업계에서 요구되는 니즈(needs)는 기술 인력을 포함해 폭넓다고 할 수 있다(IDCJ, 2014: 54 5).

\section{〈상자 1〉 일본의 개발협력인재 전직· 유동화 시례}

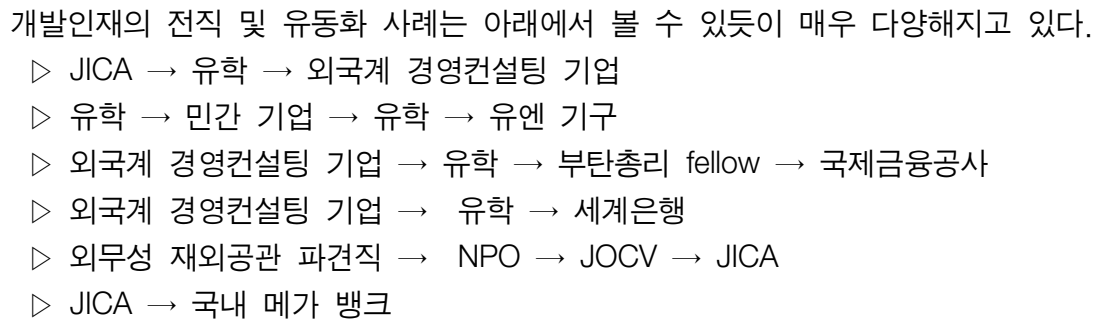

출처: IDCJ (2014) p.55 내용을 저자가 재구성

앞서 밝힌 개발협력인재 역량 요소와 변화 추세 등을 토대로 개발협력인재에 필요한 역량과 육성 방법 등을 정리하면 다음 <표 3>과 같다. 여기에 제시된 글로벌 역량 요소들은 ‘글로벌인 재육성추진회의'9) 중간 보고회에서 결정되었다(IDCJ, 2014: 56).

9) 일본 정부는 2010 년 '신성장전략실현회의'에서 각의 결정 사항으로 일본의 성장을 지원하는 글로벌 인재 육성과 활용 체계의 구축을 목표로, 특히 산학협력의 일환으로 유학 확대를 추진하기 위해 ‘글로벌인재육성추진회의’를 개최하 기로 결정했다. 여기에서 글로벌 인재 개념과 능력을 정리한 바 있다. 동 회의는 내각관방장관을 의장으로 해서 외무장 관, 문부과학장관, 후생노동장관, 경제산업장관 및 국가전략담당 장관이 위원으로 참여했다(IDCJ, 2014: 58). 
〈표 3〉 개발인재 필요 역량 및 육성 방법과 주체

\begin{tabular}{|c|c|c|c|c|}
\hline \multicolumn{2}{|c|}{ 능력 } & 위치 & 육성방법 및 주체 & 외무성 JICA 관여 \\
\hline \multicolumn{2}{|c|}{ 주체성, 적극성, 도전 정신, 협조, 유연성 } & 기본 & 개인적 소양 혹은 (학교) 기초 교육 & 없음(일부 개발교육 지원) \\
\hline \multicolumn{2}{|c|}{ 커뮤니케이션, 어학력 } & 기본 & 개인적 소양 혹은 (학교) 기초 교육 & $\begin{array}{l}\text { 없음(일부 전문가 대상 JICA 역량 } \\
\text { 강화연수 지원) }\end{array}$ \\
\hline \multirow{2}{*}{$\begin{array}{c}\text { 개발도상국을 } \\
\text { 포함한 } \\
\text { 국제이해와 경험 }\end{array}$} & 기초 이해 & 기본 & $\begin{array}{l}\text { (학교) 개발. 국제교육(JICA/NGO) } \\
\text { 개발도상국 연수 방문 }\end{array}$ & 있음(개발교육 지원) \\
\hline & $\begin{array}{l}\text { 업무 수행을 위한 } \\
\text { 전문적 이해와 경험 }\end{array}$ & 최전선 & $\begin{array}{l}\text { 유학(JICA) 개발도상국 및 협력 기 } \\
\text { 회 제공 }\end{array}$ & $\begin{array}{l}\text { 있음(NGO인재육성사업, 대학지 } \\
\text { 원사업, 일부 JICA 전문가 대상 연수 }\end{array}$ \\
\hline \multirow{2}{*}{$\begin{array}{l}\text { 개발 과제에 } \\
\text { 관한 전문성 }\end{array}$} & 개별 전문 지식 & \multirow[b]{2}{*}{ 최전선 } & 통상 고등교육(대학, 대학원) & \multirow[b]{2}{*}{ 없음(일부 JICA 전문가 대상 연수) } \\
\hline & 개발 지식 & & $\begin{array}{l}\text { 통상 고등교육(대학, 국제개발대 } \\
\text { 학원 등) }\end{array}$ & \\
\hline \multicolumn{2}{|c|}{ 국제적 리더십 } & 최전선 & $\begin{array}{l}\text { 통상 고등교육(대학, 대학원), 외무 } \\
\text { 성 }\end{array}$ & 있음(개발인재육성사업) \\
\hline
\end{tabular}

출처: IDCJ (2014) p.57 내용을 저자가 재구성 


\section{IV. 일본의 개발협력인재 육성사업 추진 현황}

\section{1. 개발협력인재 육성사업 개관}

일본의 개발협력인재 육성은 앞서 <그림 $1>$ 에서도 살펴봤듯이, 전문대학이나 대학원, 교육 기관 외에도 학교 교육 차원에서 이루어지는 국제이해교육이나 개발교육을 포함해 포괄적이고 유기적으로 연계되어 있다는 것을 알 수 있다. 아래<표 4>는 외무성과 JICA가 대체로 현장에 서 지도적 역할을 수행하는 인재 육성, 국제기구나 대사관 근무 직원의 스킬 업 등을 목표로 한 개발인재 육성사업 현황을 정리한 것이다.

앞서 언급했듯이, 일본은 개발인재와 차별화하여 JICA를 통해 NGO 인재육성 사업을 별도 로 시행하고 있다. 한국의 경우에는 1995년부터 한국국제협력단이 NGO 지원 사업을 시행한 이후 양적으로나 질적으로 그동안 많은 발전을 이루어 왔다. 앞으로도 ODA 규모 확대와 함께 시민사회, 대학, 연구소, 기업 등 다양한 민간 부문의 전문성과 경험을 개발협력 사업에 활용하 기 위해서 민간 부문의 개발협력 역량 강화에 대해서도 지원을 확대할 필요가 있다.

\section{〈표 4〉일본 정부의 개발인재 육성사업 현황}

\begin{tabular}{|c|c|c|}
\hline 사업 & 목적 & 사업 개요 \\
\hline \multicolumn{3}{|c|}{ 개발인재 육성사업 } \\
\hline $\begin{array}{l}\text { 고도 개발인재 } \\
\text { 육성(위탁) }\end{array}$ & $\begin{array}{l}\text { - 박사과정 재학생을 대상으로 실시하며, 장 } \\
\text { 래 현장에서 주도적 업무를 수행할 인재 } \\
\text { 육성을 목표로 한차원 높은 실천적인 교육 } \\
\text { 이 목표 }\end{array}$ & $\begin{array}{l}\text { - 공개 예산심의 후 사업이 재검토되어 2011년부터 } \\
\text { 새로운 고도개발인재 육성사업이 추진되고 있음. 개 } \\
\text { 발 현장에서 지도적 역할을 수행하는 인재 육성을 } \\
\text { 목적으로 협상 롤플레이, 워크숍, 미디어트레이닝 } \\
\text { 등 } 6 \text { 가지 단기 집중형 코스를 실시 }\end{array}$ \\
\hline $\begin{array}{l}\text { 개발원조연수 } \\
\text { 사업(직접 추진) }\end{array}$ & $\begin{array}{l}\text { - ODA를 효과적·효율적으로 실시하기 위해 } \\
\text { 경제협력 실무 담당자의 역량 강화가 목적 }\end{array}$ & $\begin{array}{l}\text { - 개발협력세미나 : 일본 정부에서 경제협력 업무에 } \\
\text { 종사하는 직원(주로 외무성 국제협력국 직원)을 대 } \\
\text { 상으로 일본 ODA 기본 이념, 중요 과제, 세계원조 } \\
\text { 동향과 일본의 현황 등에 관한 이해 증진을 목적으 } \\
\text { 로 실시하는 단기 집중형 세미나(연 2회) } \\
\text { - 대사관 경제협력 담당관 연수 : 재외공관 경제협력 } \\
\text { 담당관으로 부임 예정인 타 부처 공무원을 대상으로 } \\
\text { 한 ODA 연수 }\end{array}$ \\
\hline \multicolumn{3}{|c|}{ NGO 인재육성사업 } \\
\hline $\begin{array}{l}\mathrm{NGO} \text { 인턴 } \\
\text { 프로그램(외) }\end{array}$ & $\begin{array}{l}\text { - NGO 취업을 희망하는 청년 인재를 위한 } \\
\text { 문호를 넓히고, 청년 인재 육성을 통해 } \\
\text { NGO에 의한 국제협력을 확대하기 위해 인 } \\
\text { 턴 육성을 NGO에 위탁한 후 이와 관련된 } \\
\text { 소정의 경비를 지븝 }\end{array}$ & $\begin{array}{l}\text { - 국제협력에 종사하는 일본 NGO에게 청년인재를 약 } \\
10 \text { 개월간 접수실무를 통한 인재육성 업무를 위탁하 } \\
\text { 는 사업 }\end{array}$ \\
\hline
\end{tabular}




\begin{tabular}{|c|c|c|}
\hline 사업 & 목적 & 사업 개요 \\
\hline $\begin{array}{l}\mathrm{NGO} \text { 해외스터디 } \\
\text { 프로그램(외) }\end{array}$ & $\begin{array}{l}\text { - 일본 국제혈력 } \mathrm{NGO} \text { 의 인재 육성을 통한 } \\
\text { 조직 강화를 목적으로 최대 6개월 정도 일 } \\
\text { 본 NGO 소속 중견 직원을 대상으로 실시 }\end{array}$ & $\begin{array}{l}\text { - 실무 연수형 및 수강 연수형 두 가지 형태로 실시되 } \\
\text { 는데, 연수생 소속 NGO 수요를 토대로 주체적인 } \\
\text { 연수 계획 수립이 가능한 것이 특징. 연수생이나 소 } \\
\text { 속 NGO에서는 귀국 후 연수 성과를 소속 NGO 활 } \\
\text { 동에 활용해야 함 }\end{array}$ \\
\hline $\begin{array}{l}\mathrm{NGO} \text { 인재육성연 } \\
\text { 수: 조직력 향상 } \\
\text { (JICA) }\end{array}$ & $\begin{array}{l}\text { - 국내외에서 향후 활약할 } \mathrm{NGO} \text { 직원의 인재 } \\
\text { 육성을 통해 단체의 조직 강화 지원이 목적 }\end{array}$ & $\begin{array}{l}\text { - NGO에 의한 국제협력이 더욱 확실하게 개발도상국 } \\
\text { 국민 개개인에 도달될 수 있도록 NGO 직원 인재 } \\
\text { 육성을 통해 소속 단체가 안고 있는 과제 해결 대응 } \\
\text { 을 지원함으로써 NGO의 조직력 향상에 공헌 }\end{array}$ \\
\hline $\begin{array}{l}\text { NGO자문관 } \\
\text { 파견(JCA) }\end{array}$ & $\begin{array}{l}\text { - 국제협력 NGO 단체의 국내 및 해외 활동 } \\
\text { 현장에서 사업 효과 향상이 목적 }\end{array}$ & $\begin{array}{l}\text { - 전문 지식이나 기술·경험을 갖춘 인재를 NGO에 } \\
\text { 파견, } \mathrm{NGO} \text { 해외 프로젝트 강화 및 조직 강화를 } \\
\text { 위한 자문관 파견 사업 실시 }\end{array}$ \\
\hline $\begin{array}{l}\mathrm{NGO} \text {, 지자체, 대 } \\
\text { 학 등 국제협력 } \\
\text { 담당자 PCM연 } \\
\text { 수(JICA) }\end{array}$ & $\begin{array}{l}\text { - PCM 기법을 활용한 국제협렬사업 기획 입 } \\
\text { 안 및 모니터링 평가 개요를 이해해 더욱 } \\
\text { 효과적인 사업을 실시하는 게 목적 }\end{array}$ & $\begin{array}{l}\text { - PCM 기법을 활용한 국제협력사업 기획 입안(2일) } \\
\text { : PCM 기법 개론, 프로젝트 사례 분석, PDM 작성 } \\
\text { 연습 실시 } \\
\text { - PCM 기법을 활용한 국제협력사업 모니터링 평가(2 } \\
\text { 일) : PCM 기법을 활용한 모니터링 평가 개론과 프 } \\
\text { 로젝트 사례를 활용한 모니터링 평가 연습 실시 }\end{array}$ \\
\hline
\end{tabular}

출처: IDCJ (2014) pp.2 3 내용을 저자가 재구성

\section{JICA의 개발협력인재 육성 추진 체계 및 PARTNER}

\section{가. 국제협력인재부}

JICA는 2003년 10월 1일부로 새롭게 탄생했는데, 신 법인의 신규 업무로 국민이 참여하는 국제협력 활동을 촉진하기 위한 업무를 수행하게 되어 국제협력인재센터 기능을 JICA의 국제 협력인재부 내에 설치했다.10) 이는 2002년 '제2차 ODA 개혁간담회' 최종 보고서에서 국제협력 인재 발굴 및 육성과 효과적인 활용 시스템 구축에 대한 제안에 따른 것이다.11)

국제협력인재부12)는 국제협력인재센터 업무 외에 기술협력 전문가, 국제협력 전문원, 주니어 전문원 및 기획조사원, 기타 사업지원요원(전문가 등)의 양성 및 확보에 관한 기획 조정 및

10) 자세한 사항은 다음을 참조하기 바란다. http://partner.jica.go.jp/ContentViewer?prm=AboutPARTNER2 (접속일: 2017.11.29.)

11) 자세한 사항은 다음을 참조하기 바란다. http://www.mofa.go.jp/mofaj/gaiko/oda/seisaku/kondankai/ 2/kondan_last.html (접속일: 2017.11.30.)

12）獨立行政法人或際拹力機構組織規程 제 46 조 http://association.joureikun.jp/jica/act/ frame/frame110000014.htm (접속일:2017.11.01.) 참고로 해외봉사단 기획, 모집, 선발 및 훈련, 봉사단 지원, 타 기관과의 업무 협조 및 관련 지식 보급, 봉사단 경험의 사회 환원, 봉사단 훈련소 소관 업무 등은 청년해외협력대사무국이 관장하고 있다. (동 제47조 참조) 
실시에 관한 업무, 전문가 파견, 평가 및 관리(실시계획 수립 제외), 전문가 및 청년해외협력대원 등 신분 및 대우, 복리후생 관련 업무, 기타 전문가 등에 관한 업무(청년해외협력대사무국 업무 제외) 등을 관장하고 있다.

$\mathrm{JICA}$ 가 국제협력인재 전담 조직을 설치한 것은 이미 여러 차례 기술했듯이, 개발협력 분야가 더욱 복잡하고 다양화되고 있기 때문에 이러한 개발인재 수요에 부응한 인재 양성과 확보를 통해 효과적인 개발협력을 도모하기 위한 것이다. JICA가 활용하고 있는 다양한 전문 인력 유형에 대해서는 다음 절에서 살펴보겠다.

\section{나. 종합 정보 사이트 PARTNER}

$\mathrm{JICA}$ 는 국제협력 분야에서 활약을 희망하는 개인과 기관을 연결하는 플랫폼 역할을 수행하 고 있는데, 현재 PARTNER13)라는 국제협력 커리어 종합정보 사이트를 운영 중이다.

JICA는 'All Japan 국제협력 활동 촉진'이라는 이념에 따라 국제협력과 관련된 모든 사람을 위해 JICA의 정보만이 아니라 국제기구, 개발컨설팅기업, 국제협력 $\mathrm{NGO}$ 및 $\mathrm{NPO}$, 국제협력 관련 기관, 정부기관, 지방자치단체, 대학, 민간 기업 등을 망라한 국제협력 실시 기관에 관한 정보를 일원화해 체계적으로 제공하고 있다. 현재 개인 등록자는 23,000 명을 상회하고 있으며, 기업을 포함한 등록 단체가 1,000 여 곳을 넘어 구인, 연수 및 세미나, 각종 이벤트 정보를 게재 중이다.14)

\section{〈그림 6〉 JICA의 개발원조 경력개발 지원 체계}

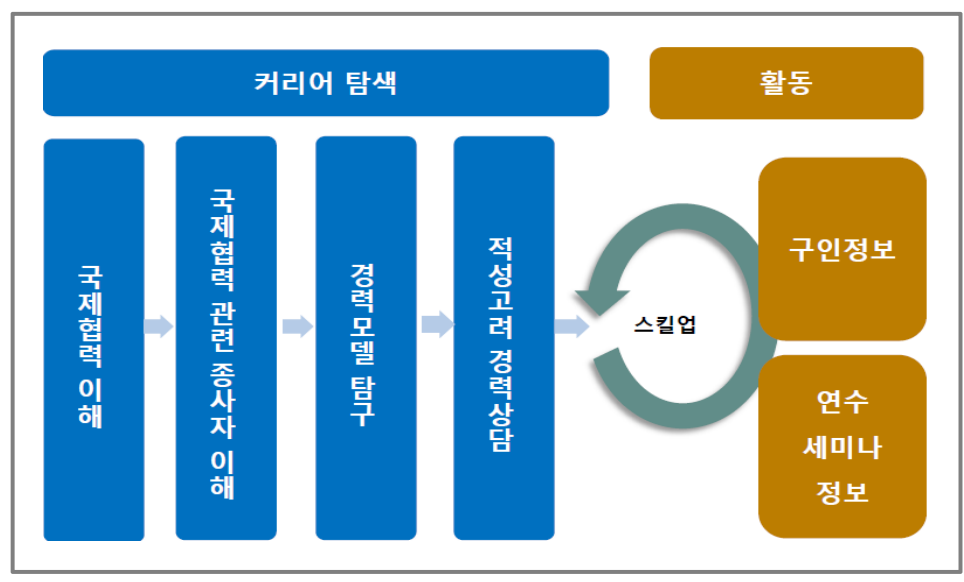

출처: JICA PARTNER 홈페이지 http://partner.jica.go.jp (접속일: 2017.10.13.)

13) http://partner.jica.go.jp/PartnerHome (접속일: 2017. 11. 27.)

14） https://www.jica.go.jp/about/report/2017/ku57pq000022ernq-att/J_37.pdf1 (접속일: 2017.11.27.) 
위 <그림 6>을 상세하게 설명하자면, 국제협력에 관심이 있으나 이 분야에 대한 이해가 부족한 경우에는 첫 번째, '국제협력 이해’ 단계에서 출발한다. 다음으로, 일본의 국제협력 업계 에 관해 알고 싶은 경우에는 두 번째인 '국제협력 관련 종사자 이해' 단계로 들어간다. 그리고 국제협력에 종사하기를 희망하나 어떤 일이나 관계가 있는지 알고 싶은 경우에는 '경력모델 탐구’ 단계에서 관련 정보를 찾아볼 수 있다. 실제로 국제협력 현장에서 활용 중인 사람은 어떤 커리어를 밟을 것인가, 혹은 자신도 국제협력 업무에 종사할 수 있는가가 궁금할 경우에는 이곳에서 여러 정보를 찾아볼 수 있다. ‘현재의 자신'과 ‘되고 싶은 자신'과 어느 정도 차이가 있는가를 알고 싶은 경우에는 '적성고려 경력상담' 단계에서 정보를 검색할 수 있다.

또 ‘구인정보’란에는 JICA, 국제기구, 정부 관계 기관, $\mathrm{NPO} \cdot \mathrm{NGO}$ 등 국제협력 실시 기관이 나 단체의 구인 정보가 게재되어 있다. 여기에는 봉사단, 인턴이나 기술과 풍부한 경험을 보유한 전문가에 이르기까지 다양한 구인 정보가 게재되어 있다. '연수·세미나 정보'에는 관련 분야의 지식을 쌓고 네트워크를 만드는 데 도움이 되는 $\mathrm{JICA}$ 를 비롯한 다양한 국제협력 관련 기관이나 단체가 개최하는 연수 및 세미나 정보가 게재되어 있다.15)

또한 젊은 사회인과 학생을 주요 대상으로 개발 원조의 최일선에서 활약하는 전문가들로부터 국제협력 업무에 관한 생생한 목소리와 관련 정보 등 동 분야의 경력 개발에 유익한 정보를 제공하고 또 국제협력 활동 참여를 독려할 목적으로 '국제협력 JOB 세미나'를 개최하고 있다. 주제는 중남미 지역, 이공계 여학생과 국제협력 등 다양하게 특화되어 있다.16)

특기 사항으로는 개발협력 분야에서도 '일과 삶의 균형(work life balance)'에 대한 관심이 높아짐에 따라 2016년도부터 '국제협력 분야 워크 라이프 밸런스 특집'을 게재 중이다. 동 분야 에서 경력 개발을 희망하는 일반인이나 학생들을 대상으로 2015년 2월부터 다양한 주제로 정기적인 워크솝을 개최 중이다.

참고로, 일본의 국제개발협력 관련 업계의 주요 조직 및 인력 현황은 아래와 같다. 정부부처나 지방자치단체, 민간 기업 등은 인원 규모가 파악되어 있지 않아 제외했다.17)

15) 자세한 사항은 다음을 참조하기 바란다. http://partner.jica.go.jp (접속일:2017.10.13.)

16) 최근 개최된 세미나에서는 내각부, 문부과학성, 경제단체연합회가 공동으로 이공계 분야에 흥미가 있는 여학생(20명 참가)을 대상으로 해서 국제협력에 관한 비디오 및 퀴즈를 통해 국제협력에 관한 이해를 돕고, 전문 강사를 초빙해 '국제협력 업무란 무엇인가'와 ‘이공계 전공이 국제협력에 어떻게 연계되는가'를 주제로 강의를 실시했다. 강사는 JICA 농촌개발부 및 사회기반 - 평화구축부 직원 2 명, 일본공영주식회사 컨설턴트 해외사업본부 환경자원사업부 직원 1 명이 참여했다. (출처: https:/www.jica.go.jp/information/seminar/2017/20170926_01.html) (접속일: 2017.10.13.)

17) 자세한 사항은 다음을 참조하기 바란다. http://partner.jica.go.jp/ContentViewer?prm=AboutField4 (접속일: 2017.11.21.) 
〈표 5〉일본 국제개발협력 주요 관련 기관 현황

\begin{tabular}{|c|c|c|c|}
\hline & 기관 개요 & 직원 & 상세 \\
\hline JICA & $\begin{array}{l}\text { - 외무성 소관 독립 행정법인 } \\
\text { - 2008년 New JICA 탄생, 유무상 ODA를 } \\
\text { 일원화해 사업을 수행 중 } \\
\text { - 폭넓은 개발 과제에 대해 풀뿌리 활동부터 } \\
\text { 국가개발계획 수립까지 종합적으로 지원. 기 } \\
\text { 술협력, 유상자금협력, 무상자금협력 지원 }\end{array}$ & $\begin{array}{l}\text { - 약 } 19,000 \text { 명 } \\
\text { - 직원: 약 } 2,000 \text { 명 } \\
\text { - 전문가: 약 } 8,000 \text { 명 } \\
\text { - 조사단원: 약 } 7,000 \text { 명 } \\
\text { - 봉사단: 약 } 2,000 \text { 명 }\end{array}$ & $\begin{array}{l}\text { - https://www.jica.go.jp } \\
\text { - PARTNER 내 } \\
\text { 구인·연수 세미나·단체 } \\
\text { 일람 검색 }\end{array}$ \\
\hline 국제기구 & $\begin{array}{l}\text { - UN 및 산하기관, 전문 기관, 국제개발금 } \\
\text { 융기관 등 } \\
\text { - 국경을 넘어 분쟁이나 테러, 환경 파괴, 감 } \\
\text { 염증, 빈곤 등 글로벌 과제를 해결하기 위 } \\
\text { 해 활동 }\end{array}$ & $\begin{array}{l}\text { - 각 기관 일본인 직원 수 } \\
\text { (2013년 기준) } \\
\text { - UN 관계 기관 : 764명 } \\
\text { - UN사무국 : 156명 } \\
\text { - UNDP : 69명 } \\
\text { - UNICEF : 71명 등 } \\
\text { * 출처: 국제기구인사센터UN 기 } \\
\text { 관 취직 가이드 }\end{array}$ & $\begin{array}{l}\text { - 유엔홍보센터: } \\
\text { http://www.unic.or.jp } \\
\text { - 일외무성국제기구인사센터 } \\
\text { http://www.mofa-irc.go.jp } \\
\text { - PARTNER 내 구인·연수 } \\
\text { 세미나·단체 일람 검색 }\end{array}$ \\
\hline $\begin{array}{c}\text { 컨설팅 } \\
\text { 기업 }\end{array}$ & $\begin{array}{l}\text { - 개발원조 전문가로서 고도의 전문 기술과 } \\
\text { 경험을 갖추고 JICA 및 국제기구 등 원조 } \\
\text { 계획 추진 } \\
\text { - 개발 계획 사전조사부터 계획 수립, 시공 감 } \\
\text { 리, 사후 평가 등 업무 내용과 분야가 다양 }\end{array}$ & $\begin{array}{l}\text { - } 65 \text { 개사 이상 개략적으로 약 } \\
\text { 2,500명 } \\
\text { *출처: } 2014 \text { 국제협력가이드 } \\
\text { (국제개발저널사 발간) }\end{array}$ & $\begin{array}{l}\text { - 컨설팅협회 HP: } \\
\text { http://www.ecfa.or.jp/ } \\
\text { japanese/index.html } \\
\text { - PARTNER 내 구인·연수 } \\
\text { 세미나·단체 일람 검색 }\end{array}$ \\
\hline $\begin{array}{c}\text { INGO 및 } \\
\text { NGO/NPO }\end{array}$ & $\begin{array}{l}\text { - 민간인 - 민간 단체 조직으로 소수 조직부 } \\
\text { 터 세계적 네트워크를 갖는 규모에 이르기 } \\
\text { 까지 사업 규모나 활동 내용이 다양 } \\
\text { - 개발도상국의 빈곤이나 자연재해, 분쟁, 인 } \\
\text { 권 등 여러 과제에 대해 민간 차원에서 현 } \\
\text { 지 수요를 파악해 유연하고 신속하게 지원 }\end{array}$ & $\begin{array}{l}\text {-500단체 이상 약 4,000명 } \\
\text { * 출처: } 2014 \text { 국제협력가이드 } \\
\text { (국제개발저널사 발간) }\end{array}$ & $\begin{array}{l}\text { - 국제협력NGO센터: } \\
\text { http://www.janic.org } \\
\text { - PARTNER 내 구인·연수 } \\
\text { 세미나·단체 일람 검색 }\end{array}$ \\
\hline $\begin{array}{l}\text { 국제협력 } \\
\text { 유관 및 } \\
\text { 지원 기관 }\end{array}$ & $\begin{array}{l}\text { - 타 조직과 연계해 고도의 전문성으로 다양 } \\
\text { 한 수요에 대응 } \\
\text { - 주요 조직은 개발도상국에서 일본기업의 } \\
\text { 자원 확보 및 개발, 인프라 시스템 수출 } \\
\text { 등 지원하는 국제협력은행JBIC), 무역투 } \\
\text { 자 촉진과 개발도상국 연구를 통해 세계경 } \\
\text { 제 발전을 도모하는 일본무역진흥기구 } \\
\text { (JETRO), 개발도상국 인재 육성을 지원하 } \\
\text { 는 일본국제협력센터(JICE), 국제협력조 } \\
\text { 달 전문 일본국제협력시스템(JICS) 등 }\end{array}$ & $\begin{array}{l}\text { - 각 기관 인원 규모(2014) } \\
\text { - JBIC: 약 530명 } \\
\text { - JETRO: 약 } 1,600 \text { 명 } \\
\text { - JICE: 약 240명 } \\
\text { - JICS: 약 } 170 \text { 명 등 } \\
\text { * 출처: 각 기관 홈페이지 등 }\end{array}$ & $\begin{array}{l}\text { - JBIC: } \\
\text { http://www.jbic.go.jp/ja } \\
\text { - JETRO: } \\
\text { https://www.jetro.go. } \\
\text { jp/indexj.html } \\
\text { - JICE: } \\
\text { http://sv2.jice.org } \\
\text { - JICS: } \\
\text { http://www.jics.or.jp }\end{array}$ \\
\hline
\end{tabular}

동 홈페이지에서는 각 기관별 채용 특징과 함께 요구되는 학력, 어학력, 실무 경험 등도 일목요연하게 정리해 제시하고 있다. 아울러 각 기관별로 여러 사례를 토대로 경력지도(career $\mathrm{map}$ )를 제시하고 있어서 관심 있는 사람들의 경력 개발에 도움을 주고 있다.18)

18) 자세한 사항은 다음을 참조하기 바란다. http://partner.jica.go.jp/ContentViewer?prm=AboutType2 (접속일: 2017.11.20.) 


\section{JICA의 국제협력 전문 인력 활용 현황}

$\mathrm{JICA}$ 는 앞서 살펴본 바와 같이 기술협력 전문가, 기획 조사원, 국제협력 전문원, 개별 전문가, 조사단원 등을 국내외에서 광범위하게 활용 중이다. JICA 홈페이지 'PARTNER' 사이트에 접속하면 각 전문 인력별로 요구되는 자질이나 자격, 주요 업무, 역량 요소 등이 자세하게 안내 되어 있다. 본 원고에서는 주요 직무 및 업무 중심으로 JICA가 활용 중인 국제협력 전문 인력을 소개하고자 한다.

기술협력프로젝트 전문가는 JICA 해외 사무소에서 수석자문관, 업무조정 담당, 기술이전 담당 등 세 가지로 구분되어 운영되고 있다. 수석자문관(Chief Advisor)은 프로젝트 전문가팀 을 총괄하며, 수원국 직원에 대한 특정 과제나 분야 등에 대한 조언·지도업무를 수행한다. 업무조정담당관은 수석자문관을 보좌하여 프로젝트 관리 및 조정 업무, JICA 본부 - 해외사무 소 - 프로젝트팀, 일본대사관, 수원국 정부 및 다른 공여국과의 업무 연락, 프로젝트 홍보 업무 등을 수행한다. 기술이전 담당 전문가는 개별 전문가 혹은 수원 기관(연구소, 훈련소, 병원 등 정부 유관기관)에 배치되어 기술을 전수하고 수원국 직원에 기술이전, 제도 및 조직 개선 등의 업무를 추진한다. 계약 기간은 일반적으로 수개월에서 2 년 정도이며, 최대 3 년까지 연장할 수 있다.

기획조사원은 기획, 봉사단 사업, 조달 등으로 구분되어 있다. 기획담당 조사원은 JICA 해외 사무소 등에서 담당 분야나 과제에 대한 정보 수집 및 분석, 원조 계획 수립, 사업 발굴 및 형성, 프로젝트 실시 감리, 공여국 협력, 모니터링 평가 등을 지원한다. 또 봉사단 사업 담당 조사원은 해외 봉사단 활동과 관련된 제반 업무를 지원하며, 수원국 개발 과제를 토대로 봉사단 파견 계획 수립 및 파견 기관 협의를 비롯해 봉사단 활동 지원, 위험 관리, 사무 및 회계 등 광범위한 업무를 담당하고 있다. 그리고 조달 담당 조사원은 전문가 및 프로젝트와 관련된 조달 업무를 지원하고, 사무소 내에서 조달 경험이나 지식의 축적 및 보급 등을 위한 업무를 수행한다. JICA 해외 사무소에는 일본 파견 직원 외에 현지 채용 직원도 근무하고 있다. 또한 기획조사원(조달)은 사무소 근무 직원이나 현장에서 활약하는 전문가가 필요로 하는 기자재 조달, 공사 계약, 컨설턴트 계약 지원 업무, 조달 가이드라인 및 서식 정비, 사무소 내 세미나 등을 통해 적정하게 조달이 수행되도록 지원하고 있다. 계약 기간은 일반적으로 수개월에서 2 년까지이며, 최대 3 년까지 갱신할 수 있다.

조사단원은 JICA가 실시하는 프로젝트의 형성 및 사업 실시 감리, 평가 등과 관련해 각종 조사 업무에 참여한다. 이들은 전문 지식을 활용해 보고서 작성 및 향후 대응 과제 등을 정리한 다. 계약 기간은 일반적으로 1 개월에서 수개월까지 다양하다. 
국제협력추진원은 ‘지역의 JICA 창구’로, 지역국제화협회 등 지자체가 실시하는 국제협력 사업의 활동 거점으로서 JICA가 배치한다. 국제협력추진원은 주로 JICA가 실시하는 사업에 대한 지원, 홍보 활동 추진, 지자체 등이 수행하는 국제협력 사업과의 연계 촉진 등 관련 업무를 수행한다. 이러한 업무를 통해 국제협력에 대한 일반 시민들의 이해 증진과 국제협력 참여 촉진, 지역 관계자와의 연계 등을 목적으로 한다.19) 주요 업무로는 (1) 지자체 및 지역국제화협회 등과 연계한 국제협력사업 홍보 활동, (2) 지자체·지역국제화협회·대학·NGO 및 기업 등이 수행 하는 국제협력사업과의 연계 추진, (3) JICA 풀뿌리 기술협력사업 추진, (4) JICA 민간 연계 사업 추진, (5) JICA의 개발교육(국제이해교육) 지원 업무, (6) JICA 봉사단사업 관련 시민 참가 촉진·지원 상담 및 귀국봉사단 활동 지원, (7) 연수 실시기관 발굴 및 지원 등이다.

재외건강관리원은 $\mathrm{JICA}$ 해외 사무소에서 $\mathrm{JICA}$ 직원, 전문가, 해외 봉사단 등의 건강관리 지원 업무를 수행하는 간호사다. 일상적인 건강 상담이나 주재국의 질병 예방 대책, 의료 정보 수집, 질병이나 사고 발생 시 현지 의료기관과 JICA 본부·의료자문의와의 가교 역할을 수행한 다. 계약 기간은 2 년이다.

〈표 6〉 JICA 개발인재 양성 및 활용 실적(2016)

\begin{tabular}{|c|c|c|}
\hline 인재 양성 & \multicolumn{2}{|c|}{ 인원 } \\
\hline 인턴(대학생, 대학원생) & \multicolumn{2}{|c|}{ 105명 } \\
\hline 해외 장기연수20) & \multicolumn{2}{|c|}{ 4명 } \\
\hline 주니어 전문원21) & \multicolumn{2}{|c|}{ 27명 } \\
\hline 능력강화연수(전문가 대상) & \multicolumn{2}{|c|}{ 23개 과정 560 명 } \\
\hline 전문가 부임 전 연수 & \multicolumn{2}{|c|}{ 365명 } \\
\hline 안전대책연수 및 훈련 & \multicolumn{2}{|c|}{ 1,658명 } \\
\hline UNHCR 연계 안전관리연수 & \multicolumn{2}{|c|}{ 27명 } \\
\hline 국제협력 전문원 & \multicolumn{2}{|c|}{ 106명 } \\
\hline 특별 촉탁 & \multicolumn{2}{|c|}{ 56명 } \\
\hline \multirow{2}{*}{$\begin{array}{c}\text { 국제협력커리어 종합정보 사이트 } \\
\text { (PARTNER) }\end{array}$} & 등록자 수 & 10,602 명 \\
\hline & 간이 등록자 수 & 12,667명 \\
\hline 정보 제공 건수(JICA 이외의 정보) & \multicolumn{2}{|c|}{ 3,703건 } \\
\hline 커리어 상담 건수 & \multicolumn{2}{|c|}{ 264건 } \\
\hline
\end{tabular}

출처: JICA (2017) 『JICA 연보』P.112

19) 자세한 사항은 다음을 참조하기 바란다. https://www.jica.go.jp/about/structure/suishin/index.html\#suishin (접속일: 2017. 10. 19.)

20) 개발양성 전문가를 목적으로 해외 대학원에 1년간 연수 기회를 제공하는 프로그램이다. (JICA, 2017: 112)

21) 중장기적으로 인재 부족 우려 분야에서 어느 정도 전문성과 직무 경험, 해외 활동 경험이 있는 인재육성 프로그램이다. 매년 15명 등이 신규로 채용되어 연수 종료 후 JICA 전문가로 부임한다. (JICA, 2017: 112) 


\section{V. 결론 및 정책적 시사점}

'더 나은 원조(Better Aid)'를 추진하기 위해서는 글로벌 이슈 및 다문화에 대한 심층적인 이해와 존중, 커뮤니케이션 능력 등 글로벌 역량과 함께 다양한 개발 분야의 전문성, 지역 전문 성, 개발 의제 및 원조행정 등 다양한 분야의 전문 지식과 경험을 갖춘 전문 인력의 양성과 확보가 매우 중요하다. 국제개발협력 분야에서도 사람이 답이다.

지금까지 살펴본 바와 같이, 일본 정부는 $\mathrm{ODA}$ 헌장이나 중기 계획 등 다양한 상위 정책 문서에서 개발협력인재 육성의 중요성을 강조하고, 실제로 JICA를 중심으로 다양한 개발인재 육성 사업을 추진 중이다. 지금까지 살펴본 일본 정부의 개발협력인재 육성 사업을 통해 얻을 수 있는 교훈을 토대로 한국 정부와 $\mathrm{KOICA}$ 에 주는 정책적 시사점을 아래와 같이 정리했다.

우선, 개발협력인재 양성이 단기적인 맞춤 교육의 몇몇 교육과정을 수강함으로써 이루어질 수 있는 것이 아니므로 정부 차원에서 국제개발협력 분야의 글로벌 인재 양성에 관한 중장기적 인 전략과 로드맵22)을 수립할 필요가 있다. 이때 외교부와 KOICA 외에도 기획재정부(한국수 출입은행), 산업통상자원부(대한무역투자진흥공사), 고용노동부(산업인력관리공단), 교육부 등 과 협의해 정부 차원에서 전략을 수립하고 또 각 분야별로 어떻게 특성화해 글로벌 인재를 육성하고 일자리를 창출할 것인지 논의할 수 있는 장과 프로세스를 구축할 필요가 있다. 특히, 일본의 사례에서도 볼 수 있듯이 글로벌 인재 양성과 개발교육은 정책적·유기적으로 연계되어 야 한다. 이때 초·중등교육에서부터 글로벌 시민으로서의 기본 소양을 키우고, 다양한 분야의 지식과 경험을 쌓음으로써 글로벌 개발협력 인재의 저변을 확대할 필요가 있다. 따라서 $\mathrm{KOICA}$ $\mathrm{ODA}$ 교육원에서도 초·중·고 학생을 대상으로 한 '미래세대교육'과 대학생 대상의 '국제개발협 력 이해증진 사업' 등을 적극 확대해 나가야 할 것이다.

둘째, JICA 국제협력인재부 국제협력인재양성센터와 같이 인재 양성과 활용을 체계적으로 추진하기 위해서는 전담 조직의 설치를 검토할 필요가 있다. KOICA ODA교육원은 2018년부 터 글로벌 인재 양성을 위한 귀국봉사단 및 영프로페셔널(청년 인턴)을 대상으로 한 보수교육을 실시할 계획이다. 따라서 월드프렌즈본부 글로벌인재양성실 소관의 ‘KOICA 개발협력커리어 센터'23)와의 연계 및 협업(역할 분담 포함) 방법과 절차에 대해 심도 있는 검토가 필요하며,

22) KOICA 내부 자료(2013) 글로벌 청년인재 양성사업 로드맵(2014 2018)

23) 동 센터는 임기를 마친 해외 봉사단 및 ODA 청년 인턴들이 자신의 경험과 역량을 취업 및 창업을 통해 발휘할 수 있도록 지원하기 위해 KOICA가 운영 중인 사이트다. 취업 컨설팅, 채용 정보 제공 및 인재 추천, 취업교육, 창업교육, 채용박람회 개최, 멘토링 등의 업무를 주요 서비스로 추진 중이며, 주)스카우트에서 실제 운영하고 있다. (출처: http://job.koica.go.kr/Info/CenterRole.aspx) (접속일: 2017.11.22.) 
업무를 체계적·효율적으로 추진하기 위해서는 관련 기능을 통합해 전담 조직을 설치하는 것도 좋은 방안이다. 또한 현 'KOICA 개발협력커리어센터' 웹사이트를 일본 JICA의 'PARTNER' 수준으로 확대·개편함으로써 동 사이트를 통해 국제개발협력 분야에서 일자리를 찾는 '사람'과 사람을 찾는 '기관'이 이곳에서 교육·상담·구직 및 구인 등 원스톱 서비스(one stop service)를 받게 된다면 운영 효율성을 제고할 수 있을 것이다. 아울러 현재 외교부의 국제기구인사센터24) 나 산업인력관리공단의 월드잡플러스25) 등과 유기적으로 연계해 운영함으로써 시너지 효과를 제고하는 방안도 함께 검토되어야 할 것이다.

셋째, 무엇보다 가장 유의해야 할 것은 우리가 양성하고자 하는 개발협력인재에 대한 정의와 핵심 역량, 달성 수준 등을 명확히 하고 또 이를 토대로 개발협력인재 육성 전략과 세부 계획이 수립되어야 한다는 점이다. 앞서 살펴봤듯이, 일본의 경우에는 다양한 개발협력인재 육성 사업 이 실제 수요와 부합하지 않거나 관련 기관 간 역할 및 달성 수준이 불분명해 이로 인한 사업 중복이나 교육의 시행착오 현상 등이 발생되고 있다(IDCJ, 2014: 53). 또 하나 유의할 점은, 개발협력인재 양성은 실제로 현장에서 사업을 기획하고 수행하며 관리할 수 있는 실행 능력을 키우는 데 초점을 맞춰야 한다는 것이다.

넷째, 개발협력인재 양성이 좋은 일자리(decent job)로 연결되기 위해서는 선순환적인 ODA 산업 생태계가 조성되어야 한다. 즉, 한국 정부가 $\mathrm{ODA}$ 경제력에 상응하는 수준으로 규모를 확대하는 것도 필요하고, 한국의 비교우위 산업 분야에서 $\mathrm{ODA}$ 확대, ODA 규모 대비 적정인력 증원, 다양한 개발인재 양성 프로그램 시행, 고용 기회 창출 및 활용 등을 통해 효과적인 개발협 력을 추진하기 위한 하드웨어 및 소프트웨어를 강화해 나갈 필요가 있다. 최근 국제개발 분야의 일자리 창출과 관련된 세미나에서 발표된 제안 중에는 한국 정부가 국제개발협력 분야에서 ‘좋은 일자리’를 늘리기 위해서는 무엇보다 ‘ODA 컨설팅산업의 육성'이 필요하다는 지적이 많았다.26) 아울러, 만성적으로 인력 부족에 시달리고 있는 $\mathrm{KOICA}$ 의 정원을 늘림으로써 한국 무상 원조의 원조 효과성과 질적 개선에 기여할 수 있다. $\mathrm{KOICA}$ 의 청년층 이직률27)이 높은

24) 동 센터는 1995년에 설립되었으나 2011년부터 동 센터 사무실을 개설하고, 한국 국민의 국제기구 진출을 본격적으로 지원하고 있다. 아울러 국제기구 공석 정보 제공, 설명회 개최, 가이드북 발간, $1: 1$ 멘토링 등 다양한 업무를 추진 중이다. (출처: http://unrecruit.mofa.go.kr/) (접속일: 2017.11.27.)

25) 산업인력관리공단이 K-Move 사업 일환으로 구축-운영 중인 해외 취업 정보망으로, 주로 해외 취업을 지원하고 있다. (출처: https://www.worldjob.or.kr/new_index.do) (접속일: 2017.11.27.)

26) $2017 \mathrm{KAIDEC}-\mathrm{UNITAR}$ 국제개발협력 워크솝(SDGs 시대의 지속 가능한 일자리 창출) 및 한국교육개발원 2017 제 4 회 교육 $\mathrm{ODA}$ 의 콘퍼런스(국제개발협력에서 나의 길을 찾다) 등에서 지적된 바 있다.

27) $\mathrm{KOICA}$ (내부 자료)의 최근 10 년간 입사자 중 이직률은 $20 \%$ 수준이다. 고용노동통계(2016)에 따르면, 국가 전체적으 로는 이직률이 $4.2 \%$ 이며, 300 인 이상 공공행정산업 분야의 이직률은 $2.2 \%$ 에 불과하다. (출처: http://laborstat. moel.go.kr/) (접속일: 2017.11.28.) 
편이기는 하지만 $\mathrm{KOICA}$ 는 국제개발협력에서 경력 개발을 원하는 많은 청년 인재가 가장 일하고 싶은 기관임에는 틀림없다. KOICA는 1991년에 창립한 이후 예산 규모는 약 49배 증가했으나 인력은 1.6 배 증가한 데 머물러 있다.28) 무엇보다 $\mathrm{KOICA}$ 의 인건비는 모두 행정성 경비로 우리나라 ODA에 계상되기 때문에 추가 재원 마련이 어렵다면, $\mathrm{KOICA}$ 전체 예산 실링(ceiling) 내에서 관련 내역을 조정하는 방안도 검토할 수 있다. 이는 KOICA 구성원만이 아니라 안정적인 조직 및 인적 역량 강화를 통해 한국 대외무상원조사업의 내실화를 도모함으로 써 모든 사람이 혜택을 입는 윈윈 전략이 될 것이다. $\mathrm{KOICA}$ 의 인력 증원 문제는 국회나 감사원 등에서도 관심을 갖고 있는 문제로, 외교부와 $\mathrm{KOICA}$ 는 그동안 이 문제를 해결하기 위해 많은 노력을 기울여 왔다. 그러나 여전히 개선되지 못하고 있는데, 앞으로 전향적인 검토와 결단이 요청된다.

마지막으로, $\mathrm{KOICA}$ 가 국민이 참여하는 개발협력 플랫폼으로서 앞으로 국제개발협력 인재 양성과 국민 참여를 확대하기 위해 ' $3 \mathrm{~S}$ 정책'을 적극 추진할 것을 제안한다. 즉, $\mathrm{KOICA}$ 가 사업 추진 과정에서 획득한 다양한 정보와 평가 및 연구 활동 등을 통해 창출하는 개발협력 지식을 개발교육 플랫폼인 KOICA ODA연구원과 ODA교육원을 통해 확산하고(spread-out), 여러 국내외 유관 기관과 협업을 통해 시너지 효과를 높이며(synergy-up), 협력 사업 규모 및 국제개 발인재 양성 사업을 확대함(scale-up)으로써 궁극적으로는 한국의 개발원조 효과성을 제고함과 동시에 국내 기업의 해외 진출 및 좋은 일자리 창출에도 기여할 수 있기를 바란다.29) KOICA 이미경 신임 이사장 취임사에서도 언급되었다시피, $\mathrm{ODA}$ 를 통한 청년 일자리 창출이 ODA 목적 은 아니지만, 역대 최고의 청년실업시대의 아픔을 외면해서도 안 된다.30) KOICA는 개발협력 인재양성 지원 사업을 통해 한국의 개발 원조 효과성 제고에도 기여하고, 공공기관으로서 글로벌 인재 양성과 좋은 일자리 창출 등 사회적 가치 실현에도 앞장서 나가야 할 것이다.

28) KOICA(2017 내부 자료)에 따르면, 1991년 직원 수(현원)는 201명, 사업비 174억 원이었다. 그리고 2017년도에는 직원 수(정규직 현원) 337 명, 사업비(보조금 등 위탁사업비 포함)는 8,493억 원이다. 직원 수 관련 무기 계약직 89 명을 포함하면 413 명으로, 이 기준으로는 창립 초기 대비 두 배 증가했다.

29) 무상 원조가 공여국의 국제적 위상 등 소프트파워 외에도 다양한 경제적 혜택(직접경비, 수출, 후속사업 연계, 고용 등)을 촉진한다는 관련 연구를 소개한다. Browne(1990)에 따르면, 공여국이 제공하는 ODA 100달러 중 75달러는 공여국의 행정성 경비, 물자 구매, 전문가 및 연수생 초청비 등으로 공여국에 환류된다. 또한 호주 국제개발청(1995)에 따르면, 원조 100 달러당 178 달러 상당의 수입(직접경비, 후속사업 연계 수입)이 호주 경제에 발생되며, 이밖에도 고용 및 산업구조조정 효과 그리고 국제화 등 간접효과도 발생된 것으로 조사되었다 (김복희, 2002: 128 참조). 최근 Max Mendez-Parra 외(2017)에 따르면, 영국 ODA 1달러당 0.22달러 무역 증가, 12,000 명의 일자리가 창출된 것으로 분석되었다. 윤유리(2017)는 중력 모형을 활용한 KOICA 무상 원조의 국내 수출 및 고용 효과를 분석한 결과, KOICA ODA $1 \%$ 증가 시 한국의 수출은 $0.04 \%$ 증가하며, 무상 원조에 따른 수출 고용은 전체 고용의 $0.51 \%$ 를 차지했으며, 이중 숙련노동이 약 $51.3 \%$ 를 차지한다고 분석했다.

30 ) '한국국제협력단 제 12 대 이사장 취임사'는 KOICA 홈페이지 내 '연설/기고/인터뷰'란에서 확인 가능하다. (출처: http://www.koica.go.kr/) (접속일: 2017.12.13.) 
한편, 공여국의 개발원조 동기는 정치적·경제적·인도주의적 차원에서 복합적으로 작용한다는 점은 주지의 사실이다. 그러나 유념해야 할 것은, 단기적 국익에 집착하기보다는 진정성을 갖고 국제 규범과 원칙에 맞는 개발협력을 추진함으로써 우리나라의 스마트파워(smart power)를 증진하는 것이 궁극적으로 국익에 도움이 된다는 점을 다시 한 번 강조하고 싶다.

〈표 7〉 주요 공여국 개발협력 인재양성 프로그램 개요

공여국 및 공여 기관 개발협력 인재양성 프로그램 개요

대학 및 대학원 재학생을 대상으로 한 국제개발협력 인턴십, KOICA 해외 사무소 - 국내 유관기관 · 재외공관 근무 영프로페셔널(청년 인턴) 파견. 귀국 봉사단 및 영프로페셔널을

대한민국 $\mathrm{KOICA}$

(Korea International

Cooperation Agency)

일본 JICA (Japan International Cooperatioin Agency)

미국 USAID

(United States Agency for International Development)

영국 DFID(Department for International Development)

캐나다 GAC

(Global Affairs Canada)

호주 DFAT

(Department of Foreign Affairs and Trade) 대상으로 한 커리어개발센터 운영 및 귀국 봉사단 장학생 선발 지원. 아울러, ODA교육원을 통해 국제협력 이해 증진을 위한 일반 과정, 개발 주제 및 지역 등 심화 과정, 중소기업 맞춤 과정, 대학생 국제개발협력 이해증진 과정(공모제) 등을 통해 전문 인력 양성 추진. 2018년부터 글로벌 인재 양성을 위한 귀국 봉사단 및 청년 인턴 보수교육 및 취 · 창업교육 추진 예정.

대학 및 대학원생 인턴, 해외 연수, 주니어 전문원 등 프로그램 지원. 국제협력인재부 국제협 력인재센터가 운영하는 국제협력인재종합사이트 'PARTNER'를 통해 인재와 기관을 연결하 는 플랫폼 운영. 다양한 연수 - 세미나 - 각종 이벤트 정보 제공 중으로, 개인 등록자 수 22,000 여 명, 기관 수 1,000 여 곳에 달함. JICA 해외 사무소를 비롯해 국내외에서 기술협력 전문가, 기획조사원, 조사원, 국제협력 전문원(지자체 파견), 재외건강 관리원 등 다양한 전문 인력을 활용해 개발협력 경력 개발에 기여.

보건 - 민주주의 · 과학기술·여성 권리 등의 분야에서 펠로우십 프로그램(Fellows Programs)을 운영 중이며, 펠로우는 직무 연수·순환 배치·정규 훈련 기회 등을 통해 위싱턴 본부 및 해외 사무소에서 다양한 실무 경험을 쌓은 후 진로 선택 및 경력 개발에 기여. 주 업무는 본부 혹은 해외에서 1 2년간 기술자문 제공, 연구논문 작성 및 평가 방법 개발 등. Foreign Service Junior Officer Program은 12 18개월간 워싱턴 D.C.에서 외국어 를 포함한 정규 훈련 후 순환 배치. 무급 인턴, 유급 인턴의 경우 정규직 전환형과 체험형 인턴 운영 등.

DFID에서 직접 운영하는 인턴십 프로그램이나 인재양성 지원 프로그램은 없음. Think Global 등 개발교육 기관들을 통해 초 - 중 - 등 국제개발교육에 연간 8백만 파운드 지원.

캐나다 GAC는 미주기구(OAS) 장학 프로그램을 통해 교육, 사회 개발, 경제, 지속 가능한 발전 분야 등 지원. 국제개발연구센터(IDRC)는 개발도상국에서 개발 - 연구 장학금 지원제도 운영. 캐나다 정부 차원에서 통합적으로 인턴십 등 지원.

DFAT는 원조 프로그램의 일환으로 장학금(Australia Awards) 지원을 통해 개발도상국뿐만 아니라 호주 인재도 지원. 전문가 육성을 위해 호주 대학생들의 아시아 - 태평양 지역 유학, 인턴십, 멘토링 및 연구 등을 지원하는 New Colombo Plan 시행. 기타 인도주의적 지원에 기반을 둔 인재 양성을 위해 UN Sand-By- Partnership Program을 RedR Australia에 위탁 실시.

출처: 관련 홈페이지 등을 참조해 저자가 재구성 


\section{참고 문헌}

국제개발협력학회. 2017. "KAIDEC-UNITAR 국제개발협력워크솝 자료집: SDGs 시대의 지속 가능한 일자리 창출”(2017.11.24. 26., 제주대학교, 제주국제연수센터에서 개최) 김복희. 2002. “선진국의 공적개발원조(ODA) 동기와 유형에 관한 비교 연구." 연세대학교 행정대학원 석사학위 논문.

. 2017. “일본의 국제교육 및 개발교육 지원사업 현황과 시사점.” 『국제개발협력』 2017년 제3호.

윤유리. 2017. 『KOICA 무상 원조의 국내 수출 및 고용에 미치는 영향에 관한 연구: 패널 중력 모형 분석을 중심으로』. 성남: 한국국제협력단.

한국교육개발원. 2017. “제4회 교육 ODA 컨퍼런스 자료집: 국제개발협력에서 나의 길을 찾다.”(2017.12.19. 서울 코엑스에서 개최)

. 2017. “국제개발협력 분야 글로벌 인재 양성 및 양질의 일자리 창출을

위한 ‘보수교육 및 경력 진로 컨설팅' 추진 계획(안)”(내부 자료). 성남. 한국국제협력단. 한국국제협력단. 2016. “KOICA 역량 모델 및 CDP 기반 교육훈련 체계”(내부 자료). 성남: 한국국제협력단.

IDCJ. 2014. “開發人材育成及び開發呚育支援の評価(第三者訴価) 報告書.”東京：株式會 社國際開發センタ(International Development Center of Japan, IDCJ).

JICA. 2008. 課題別指金十市民參加. 東京 : 獨立行政法人國際協力機構(Japan International Cooperation Agency, JICA).

. 2017. 『JICA 2017 Annual Report』. 東京 : 獨立行政法人國際協力機構(Japan International Cooperation Agency, JICA).

Max Mendez-Parra and Dirk Willem te Velde. 2017. "Aid, exports and employment in the UK." Briefing note. London: Overseas Development Institute(ODI).

OECD. 2005. "Managing Aid: Practices of DAC member countries." Paris: Organization for Economic Cooperation and Development(OECD).

. 2016. "Global competency for an inclusive world." Paris: Organization for Economic Cooperation and Development(OECD).

고용노동부 고용노동통계 홈페이지: http://aborstat.moel.go.kr (접속일: 2017.11.28.) 산업인력관리공단 월드잡 홈페이지: https://www.worldjob.or.kr/new_index.do (접속일: 2017.11.27.) 
외교부 국제기구인사센터 홈페이지: http://unrecruit.mofa.go.kr/overview/unwork.jsp (접속일: 2017.11.27.)

한국교육개발원 교육통계 홈페이지: https://kess.kedi.re.kr/index (접속일: 2017.11.27.) 호주 외교통상부(DFAT) 홈페이지: http://dfat.gov.au/aid/Pages/australias-aidprogram.aspx (접속일: 2017.11.27.)

영국 국제개발처(DFID) 홈페이지: https://www.gov.uk/government/organisations/ department-for-international-development (접속일 : 2017.11.27.)

캐나다 Global Affairs Canada (GAC) 홈페이지: http://international.gc.ca/worldmonde/issues_development-enjeux_developpement/involved-participer/inde x.aspx?lang=eng (접속일: 2017.11.27.)

일본 국제협력기구(JICA) 홈페이지: https://www.jica.go.jp/ (접속일: 2017.11.27.) 미국 국제개발처(USAID) 홈페이지: https://www.usaid.gov/work-usaid/careers/ fellows-program(접속일: 2017.11.27.) 